\title{
Kinerja Kader dalam Pencegahan Stunting: Peran Lama Kerja sebagai Kader, Pengetahuan dan Motivasi
}

\section{The Cadre Performa in Stunting Prevention: Rule of Working Duration as Cadre, Knowledge, and Motivation}

\author{
Irma Afifa \\ Program Studi Magister Kebidanan Fakultas Kedokteran Universitas Brawijaya Malang
}

\begin{abstract}
ABSTRAK
Salah satu upaya penanganan stunting melalui keterlibatan kader posyandu. Tujuan penelitian untuk menguji peranan pengetahuan dan motivasi sebagai variabel mediasi pengaruh lama menjadi kader terhadap kinerja kader dalam program pencegahan stunting di wilayah Puskesmas Pagelaran dan Gedangan. Metode penelitian menggunakan observasional analitik dengan pendekatan cross sectional. Populasi penelitian adalah dua puskesmas (705 kader), dengan sampel125 kader pada masing-masing puskesmas diambil secara proportional cluster random sampling. Kriteria responden yaitu kader posyandu yang aktif bekerja di wilayah Puskesmas Pagelaran atau Gedangan. Instrumen penelitian menggunakan kuesioner. Analisis uji beda Independet Sample T-Test digunakan untuk membandingkan lama menjadi kader, pengetahuan, motivasi, dan kinerja kader antara dua puskesmas. Analisis jalur digunakan untuk mengetahui pengaruh lama menjadi kader terhadap kinerja kader yang dimediasi pengetahuan dan motivasi kader pada masing-masing wilayah puskesmas. Transformasi data terlebih dulu dilakukan untuh merubah data ordinal menjadi interval dan dilakukan uji kesetaraan pada karakteristik responden meliputi usia, pendidikan, dan pekerjaan. Hasil penelitian menunjukkan pengetahuan dan kinerja kader terbukti berbeda signifikan, sedangkan lama menjadi kader dan motivasi kader tidak berbeda signifikan di kedua wilayah Puskesmas. Berdasarkan hasil analisis jalur pengetahuan dan motivasi kader tidak terbukti menjadi variabel mediasi lama menjadi kader terhadap kinerja kader serta lama menjadi kader tidak berpengaruh terhadap kinerja kader di kedua wilayah. Meskipun demikian, motivasi kader berpengaruh dominan terhadap kinerja kader di kedua wilayah Puskesmas.
\end{abstract}

Kata Kunci: Kinerja kader, lama menjadi kader, motivasi, pengetahuan, stunting

\begin{abstract}
One of the stunting handling efforts is empowerment and involvement of Maternal and Child Health Service (Posyandu) cadres. The purpose of the study was to examined the role of knowledge and motivation as the mediating variables of the influence of cadres on their performance in stunting prevention programs in Pagelaran and Gedangan Health Centers. This study used an analytical observation design with the cross sectional approach. The population cadres in two areas (705 cadres), with 125 cadres in each health center were taken proportionally using cluster random sampling. Respondent criteria were posyandu cadres who were actively working in Pagelaran or Gedangan Health Center. The research instrument was questionnaires. Analysis of Independent Sample T-Tests was conducted to compare the duration of being cadre, knowledge, motivation, and performance of cadres. Path analysis was used to find out the influence of the duration of cadre on the cadre performance mediated by cadre's knowledge and motivation in each area. Data transformation was first carried out to change ordinal data into intervals, and equality tests were conducted on the characteristics of respondents, including age, education, and occupation. The results show that cadre knowledge and performance proved to be significantly different, while the duration of time being a cadre and cadre motivation did not differ significantly in the two areas. Based on the results of the path analysis, knowledge and cadre motivation were not proven to be mediating variables because the length of time being a cadre did not affect the performance of cadres in both areas. Nevertheless, cadre motivation has a dominant influence on cadre performance in both areas.
\end{abstract}

Keywords: Cadre performance, cadres work period, knowledge, motivation, stunting

Korespondensi: Irma Afifa. Program Studi Magister Kebidanan Fakultas Kedokteran Universitas Brawijaya Malang, Jl. Veteran 65145, Malang Tel.081234426402 Email: afican13@gmail.com

DOI: http://dx.doi.org/10.21776/ub.jkb.2019.030.04.19 


\section{PENDAHULUAN}

Stunting merupakan kondisi status gizi berdasarkan panjang atau tinggi badan menurut umur bila dibandingkan dengan standar baku WHO-MGRS (Multicentre Growth Reference Study) tahun 2005, dengan nilai z-score kurang dari-2SD (1). Prevalensi balita stunting di Indonesia dari tahun 2007-2011 pada kelompok umur 0-5 bulan sebanyak $31,1 \%-36,6 \%$, pada kelompok umur 6-23 bulan sebanyak 38,2\%-39,2\%, dan pada kelompok umur 24-59 bulan sebanyak 40,2-41,7\% (1). Hal tersebut menunjukkan sepanjang periode waktu dari tahun 2007-2013 prevalensi balita stunting semakin meningkat. Data lain menyebutkan terdapat 100 daerah prioritas stunting termasuk salah satu di dalamnya yaitu wilayah Malang dengan angka stunting sebanyak 27,28\% atau sejumlah 57.372 balita (2). Berdasarkan data Dinkes Kabupaten Malang disebutkan bahwa prevalensi stunting tertinggi berada di wilayah Puskesmas Pagelaran sejumlah $27,72 \%$, sedangkan prevalensi terendah stunting terdapat di wilayah Puskesmas Gedangan sejumlah 0,15\% $(2,3)$.

Adanya keterlibatan kader dalam pengimplementasian program stunting bersesuain dengan pilar penanganan stunting di Indonesia pada point ke-3 yaitu konvergensi, koordinasi, dan konsolidasi program nasional, daerah, dan masyarakat. Disebutkan dalam Permendes PDTT No. 19 tahun 2017 pada point ke-9 yaitu penyelenggaraan dan pemberdayaan masyarakat dalam promosi kesehatan dan gerakan masyarakat hidup sehat yang didalamnya mencakup sub-point adanya keterlibatan kader posyandu dengan melakukan pertemuan kader posyandu (4).

Penelitian menyebutkan lama kerja menjadi kader berpengaruh signifikan terhadap peningkatan kinerja kader, dikarenakan kader dengan masa jabatan sebagai kader yang lebih lama, dapat lebih meningkat kemampuan dan ketrampilannya dan berpengaruh terhadap kinerja kader (5). Pengetahuan kader yang baik juga turut berpengaruh terhadap kinerja kader posyandu (6). Begitupun dengan adanya motivasi kader yang baik berpengaruh terhadap peran kader yang terlaksana semakin baik (7).

Lokasi penelitian dilakukan di dua wilayah Puskesmas Kabupaten Malang yaitu Pagelaran dan Gedangan. Hal ini dikarenakan Kabupaten Malang termasuk 100 wilayah prioritas stunting dengan persentase prevalensi tertinggi stunting sejumlah 27,72\% berada di Puskesmas Pagelaran dan persentase prevalensi stunting terendah sejumlah 0,15\% berada di Puskesmas Gedangan (3). Pengambilan sampel di dua wilayah ini untuk kemudian dibandingkan hasil akhirnya sehingga dapat diketahui seberapa jauh pengaruh lama menjadi kader terhadap kinerja kader yang dimediasi oleh pengetahuan dan motivasi kader diantara dua wilayah tersebut yang terkategori dalam 100 Kabupaten prioritas stunting. Dengan demikian, tujuan penelitian ini untuk membandingkan peranan pengetahuan dan motivasi sebagai variabel mediasi pengaruh lama menjadi kader terhadap kinerja kader dalam program pencegahan stunting di wilayah Puskesmas Pagelaran dan Puskesmas Gedangan.

\section{METODE}

Desain penelitian ini menggunakan observasional analitik dengan pendekatan cross sectional. Tujuan penelitian bersifat komparatif yaitu membandingkan antara dua wilayah Puskesmas Pagelaran dan Gedangan. Wilayah Puskesmas Pagelaran memiliki jumlah prevalensi stunting terbanyak di seluruh Kabupaten Malang sebanyak 27,72\%, sedangkan Puskesmas Gedangan memiliki jumlah prevalensi stunting terendah di seluruh Kabupaten Malang sebanyak, 0,05\% (3). Studi komparatif penelitian ini dilakukan dengan cara membandingkan pengaruh lama menjadi kader, motivasi, serta pengetahuan yang dimiliki kader terhadap kinerja kader posyandu di masing-masing Puskesmas Pagelaran dan Puskesmas Gedangan. Penelitian ini dilakukan di wilayah Puskesmas Pagelaran dan Gedangan pada bulan Februari-Maret 2019. Instrumen penelitian yang digunakan adalah kuesioner untuk mengukur pengetahuan, motivasi, dan kinerja kader.

\section{Populasidan Sampel}

Populasi dalam penelitian ini adalah seluruh kader posyandu balita di wilayah Puskesmas Pagelaran dan Gedangan sejumlah 705 kader. Sampel penelitian ini sejumlah 250 kader dengan pembagian 150 kader di wilayah Puskesmas Pagelaran dan 150 kader di wilayah Puskesmas Gedangan yang dihitung dengan rumus besar sampel untuk uji hipotesis dua populasi. Pengambilan sampel dilakukan dengan cara proportional cluster random sampling di masing-masing wilayah Puskesmas Pagelaran dan Gedangan. Seluruh kader di setiap desa diberi kode berupa angka sesuai dengan nama yang tercantum di data kelurahan. Kode yang berupa angka tersebut ditulis dikertas dan di gulung, kemudian diambil sebanyak distribusi sampel masing-masing desa. Jumlah desa di Kecamatan Pagelaran terbagi dalam 10 desa sedangkan jumlah desa di Kecamatan Gedangan terbagi dalam 8 desa sehingga keseluruhan sampel sesuai dengan distribusi sampel masing-masing desa. Kriteria sampel yang digunakan adalah pendidikan minimal SD dan bersedia berpartisipasi dalam penelitian.

\section{Analisis Data}

Penelitian ini menggunakan analisis uji beda untuk membandingkan variabel lama menjadi kader, pengetahuan, motivasi, dan kinerja kader. Perbandingan mekanisme di masing-masing wilayah Puskesmas Pagelaran dan Gedangan dianalisis menggunakan analisis jalur. Analisis jalur digunakan untuk mengetahui peranan pengetahuan dan motivasi sebagai variabel mediasi pengaruh lama menjadi kader terhadap kinerja kader posyandu dalam program pencegahan stunting (5-7) di wilayah Puskesmas Pagelaran dan Gedangan. Analisis data menggunakan SPSS windows versi 25 . Sebelum dilakukan analisis uji beda terlebih dulu kemudian dilakukan transformasi data ordinal menjadi data interval. Dilakukan uji kelayakan meliputi uji homogenitas pada karakteristik responden meliputi usia, pendidikan, dan pekerjaan dan dilakukan uji normalitas data pada variabel penelitian.

\section{HASIL}

Berdasarkan demografi kader pada wilayah Puskesmas Pagelaran pada Tabel 1 didapatkan persentase terbanyak sejumlah 23,2\% kader berusia 34-40 tahun, 38,4\% berpendidikan SMP, dan 70,4\% bekerja sebagai ibu rumah tangga. Sebaliknya di wilayah Puskesmas Gedangan persentase terbanyak sejumlah $32,0 \%$ juga berusia $41-47$ tahun, 36,8\% berpendidikan SMP, dan 37,6\% bekerja sebagai ibu rumah tangga. 
Tabel 1. Karakteristik umum kader Puskesmas Pagelaran dan Gedangan

\begin{tabular}{|c|c|c|c|c|c|}
\hline \multicolumn{2}{|c|}{ Karakteristik } & \multicolumn{4}{|c|}{ Puskesmas } \\
\hline & & \multicolumn{2}{|c|}{ Pagelaran } & \multicolumn{2}{|c|}{ Gedangan } \\
\hline & & n & $\%$ & $\mathrm{n}$ & $\%$ \\
\hline Usia Kader & $20-26$ & 10,0 & 8,0 & 10,0 & 8,0 \\
\hline \multirow[t]{10}{*}{ (tahun) } & $27-33$ & 27,0 & 21,6 & 23,0 & 18,4 \\
\hline & $34-40$ & 29,0 & 23,2 & 40,0 & 32,0 \\
\hline & $41-47$ & 25,0 & 20,0 & 28,0 & 22,4 \\
\hline & $48-54$ & 23,0 & 18,4 & 17,0 & 13,6 \\
\hline & $55-61$ & 9,0 & 7,2 & 6,0 & 4,8 \\
\hline & $62-68$ & 2,0 & 1,6 & 0,0 & \\
\hline & $69-75$ & 0,0 & 0,0 & 1,0 & \\
\hline & Total & 125,0 & 100,0 & 125,0 & 0,0 \\
\hline & & & & & 0,8 \\
\hline & & & & & 100,0 \\
\hline \multirow[t]{5}{*}{ Pendidikan } & SD & 25,0 & 20,0 & 29,0 & 23,2 \\
\hline & SMP & 48,0 & 38,4 & 46,0 & 36,8 \\
\hline & SMU & 44,0 & 35.2 & 39,0 & 31,2 \\
\hline & PT & 8,0 & 6,4 & 11,0 & 8,8 \\
\hline & Total & 25,0 & 100,0 & 125,0 & 100,0 \\
\hline \multirow[t]{6}{*}{ Pekerjaan Kader } & IRT & 88,0 & 70,4 & 73,0 & 58,4 \\
\hline & Swasta & 24,0 & 19,2 & 28,0 & 22,4 \\
\hline & Petani & 6,0 & 4,8 & 15,0 & 12,0 \\
\hline & Guru & 6,0 & 4,8 & 9,0 & 7,2 \\
\hline & Perawat & 1,0 & 0,8 & 0,0 & 0,0 \\
\hline & Total & 125,0 & 100,0 & 125,0 & 100,0 \\
\hline
\end{tabular}

Hasil (Tabel 2) menunjukkan tidak terdapat perbedaan lama menjadi kader di kedua Puskesmas, perbedaan signifikan ditemukan pada variabel pengetahuan, motivasi, dan kinerja. Meskipun secara statistik tidak ada perbedaan bermakna durasi lama menjadi kader di wilayah Pagelaran lebih lama dibandingkan di wilayah Puskesmas Gedangan. Kader di wilayah Puskesmas Pagelaran (dengan angka stunting yang lebih tinggi) memiliki pengetahuan, dan kinerja yang lebih rendah dan signifikan secara statistik bila dibandingkan kader di wilayah Puskesmas Gedangan.

Tabel 2. Hasil uji beda lama menjadi kader

\begin{tabular}{lrrr}
\hline \multirow{2}{*}{ Variabel } & \multicolumn{2}{c}{ Puskesmas } & Sig.2 \\
& Pagelaran & Gedangan & tailed \\
\hline Lama Menjadi Kader & 2.1760 & 2.0880 & 0,375 \\
Pengetahuan Kader & 69,96 & 79,44 & 0,00 \\
Motivasi Kader & 41,78 & 43,17 & 0,084 \\
Kinerja Kader & 80,22 & 86,27 & 0,001 \\
\hline
\end{tabular}

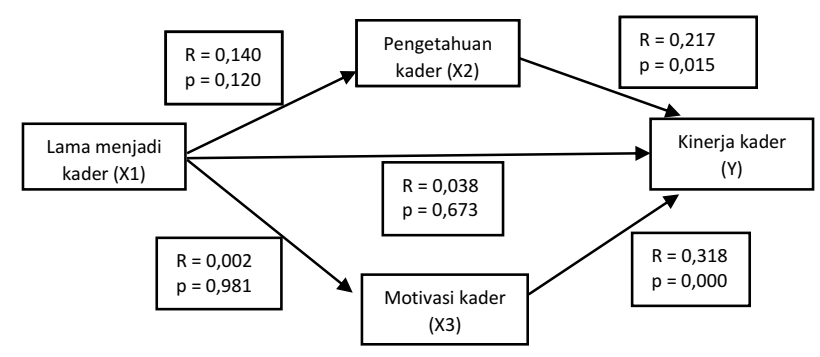

Gambar 1. Hasil analisis jalur perbandingan lama menjadi kader terhadap kinerja kader posyandu yang dimediasi pengetahuan dan motivasi kader pada program pencegahan stunting di wilayah Puskesmas Pagelaran
Analisis jalur (Gambar 1) menunjukkan bahwa pada Puskesmas Pagelaran lama menjadi kader tidak mempunyai pengaruh langsung terhadap kinerja, maupun tidak langsung melalui pengetahun dan motivasi. Secara langsung, lama menjadi kader juga tidak berpengaruh terhadap pengetahuan dan motivasi kader. Sebaliknya motivasi dan pengetahuan kader menjadi variabel yang mempunyai pengaruh langsung dan signifikan terhadap kinerja dengan explaining variance yang lebih besar pada variabel motivasi $(31,8 \%)$.

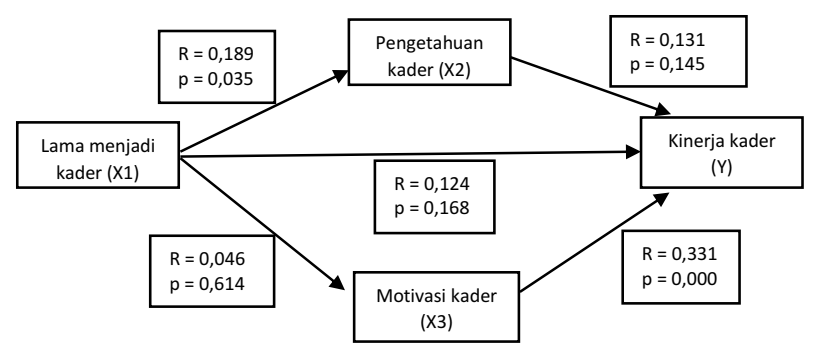

Gambar 2. Hasil analisis jalur perbandingan lama menjadi kader terhadap kinerja kader posyandu yang dimediasi pengetahuan dan motivasi kader pada program pencegahan stunting di wilayah Puskesmas Gedangan

Hasil yang berbeda didapatkan dari analisis jalur pada kader di Puskesmas Gedangan. Lama menjadi kader tidak berpengaruh secara langsung maupun tidak langsung terhadap kinerja kader, namun lama menjadi kader berpengaruh signifikan terhadap pengetahuan meskipun besar pengaruhnya keci (18,9\%). Lama menjadi kader tidak berpengaruh terhadap motivasi. Berbeda dengan hasil di Puskesmas Pagelaran, hanya motivasi yang berpengaruh secara langsung dan signifikan terhadap kinerja, sedangkan pengetahuan tidak.

Hasil analisis jalur di kedua wilayah puskesmas menjelaskan bahwa secara langsung maupun tidak langsung melalui variabel pengetahuan dan motivasi, lama menjadi kader tidak berpengaruh terhadap kinerja kader. Variabel motivasi merupakan faktor yang konsisten berpengaruh terhadap kinerja kader di kedua Puskesmas.

\section{DISKUSI}

Hasil menunjukkan tidak terdapat perbedaan lama menjadi kader di kedua wilayah Puskesmas. Pada Puskesmas Gedangan dengan kasus stunting terendah mempunyai pengetahuan dan kinerja yang lebih baik dan signifikan dibanding Puskesmas Pagelaran. Hasil analisis jalur di masing-masing wilayah Puskesmas Pagelaran dan Gedangan menunjukkan bahwa pengetahuan dan motivasi bukan merupakan variabel mediasi pengaruh lama menjadi kader terhadap kinerja kader. Meskipun demikian, motivasi kader berpengaruh signifikan terhadap kinerja kader posyandu di masing-masing wilayah Puskesmas Pagelaran dan Gedangan.

Lama menjadi kader tidak berbeda di kedua Puskesmas dan tidak berpengaruh terhadap kinerja kader di kedua wilayah Puskesmas Pagelaran dan Gedangan baik secara langsung maupun tidak langsung. Hasil penelitian ini bertolak belakang dengan penelitian lain yang menyebutkan bahwa lama menjadi kader berpengaruh terhadap kinerja kader dikarenakan kader dengan masa 
jabatan yang lebih lama, dapat lebih meningkatkan kemampuan dan ketrampilannya (5). Fakta lain menunjukkan lama menjadi kader tidak berpengaruh siginifikan meningkatkan kinerja kader di kedua wilayah Puskesmas Pagelaran dan Gedangan dikarenakan lama periode waktu menjadi kader tidak diimbangi dengan pengadaan upgrade pengetahuan dan ketrampilan secara rutin di masing-masing wilayah. Sebaliknya, rutinitas kader posyandu yang dilakukan cenderung monoton seputar pendataan, pengumpulan data, dan pelaksanaan posyandu. Adanya pengadaan pelatihan kader serta supervisi yang terpantau sangat dibutuhkan untuk mengoptimalkan kinerja kader (8).

Kader di wilayah Puskesmas Gedangan memiliki pengetahuan yang lebih baik dibandingkan pengetahuan kader di wilayah Puskesmas Gedangan. Hasil wawancara dengan beberapa kader setempat menunjukkan, bidan tetap rutin memantau dan mengendalilan pelaksanaan posyandu di masing-masing wilayah kerjanya, melaksanakan pendataan dan pendampingan adanya kasus balita stunting, dan mengadakan pertemuan kader secara rutin meskipun antar wilayah di Puskesmas Gedangan terletak sangat berjauhan. Penelitian lain menunjukkan support system yang kondusif dengan adanya pendampingan dari tenaga kesehatan setempat dapat meningkatkan pengetahuan kader posyandu (9). $\mathrm{Hal}$ ini sejalan dengan pendapat Roberton bahwa salah satu upaya penguatan tugas kader dengan melakukan pendampingan rutin dan evaluasi yang terkontrol dapat menjadikan kader merasa dipedulikan dan diperhatikan (10).

Kinerja kader di wilayah Puskesmas Gedangan lebih baik dibandingkan kader di wilayah Puskesmas Pagelaran yang dipengaruhi oleh motivasi. Penelitian lain menjelaskan bahwa kinerja kader yang optimal banyak dipengaruhi dengan adanya motivasi kader yang tinggi $(11,12)$. Analisis jalur menunjukkan bahwa peran motivasi kader merupakan faktor dominan yang berpengaruh terhadap kinerja kader di kedua wilayah. Motivasi tersebut membentuk kepribadian kader menjadi lebih passionate untuk menjalankan tugas dan kewajiban sebagai kader (13). Oleh sebab itu, penting membentuk dan menjaga lingkungan kader agar tetap kondusif terutama salah satunya dengan cara memberikan dukungan moril dari keluarga terdekat ataupun lingkungan sekitar kader misalnya dari tenaga kesehatan (14).

Motivasi yang timbul tidak terlepas dari adanya peran serta dukungan dari lingkungan terdekat kader yaitu keluarga inti ataupun lingkungan luar kader seperti support dari sesama anggota kader maupun tenaga kesehatan setempat. Penelitian terkait sumber motivasi kader di wilayah Tanzania menemukan bahwa motivasi yang tinggi dapat ditimbulkan melalui adanya dukungan dari keluarga terdekat (15). Penelitian tersebut menunjukkan terdapat korelasi positif antara dukungan yang diberikan dengan kepercayaan diri yang meningkat. Sebaliknya, minimnya support yang diberikan termasuk adanya underestimated dari tenaga kesehatan ataupun supervisor di atasnya menyebabkan kader menjadi rendah diri dan merasa tidak berwewenang penuh dalam mengoptimalkan kinerjanya (16).

Dukungan tersebut juga dapat membuat seseorang kader merasa lebih bermakna dalam menjalankan tugas dan fungsinya sebagai kader kesehatan posyandu. Berdasar teori Maslow seorang individu membutuhkan kebermaknaan dalam hidupnya untuk dapat mengaktualisasikan dirinya menjadi pribadi yang lebih baik. Kader dengan motivasi yang tinggi berkebutuhan untuk tetap dapat mengisi hidupnya dengan hal positif agar hidupnya menjadi lebih berarti. Konsep Emotional Spiritual Quotient menjelaskan bahwa pada bagian dalam otak lymbic sytem terdapat fungsi God spot (titik Tuhan). Hal tersebut mendorong seseorang untuk mencari kebermaknaan hidupnya, termasuk di dalamnya pencarian makna untuk apa dia hidup, dan bagaimana nanti dia dikembalikan setelah menjalani proses kehidupan dan berakhir dengan kematian (17).

Semakin tinggi tingkat motivasi yang dimiliki kader maka kinerjanya akan semakin baik. Hal ini sejalan dengan penelitian lain yang menjelaskan bahwa adanya motivasi yang tinggi dapat meningkatkan keaktifan kader lebih baik yang juga berpengaruh terhadap kualitas kinerjanya dibandingkan dengan kader yang memiliki motivasi rendah (18). Adanya semangat sosial yang tinggi membentuk kader termotivasi untuk menginspirasi, mengantusiasi, mengaktivasi, menstimulasi, menggerakkan, serta memotivasi masyarakat untuk lebih hidup sehat (19). Semangat altruistik pada diri kader untuk dapat memberdayakan dirinya bagi kebermanfaatan bersama merupakan salah satu dorongan motivasi yang membuat kader dapat bekerja secara optimal (12). Greenspan menyebutkan adanya dukungan motivasi dari keluarga terdekat juga turut berpengaruh besar terhadap motivasi kader dalam menjalankan tugasnya (15). Faktor lain yang juga berpengaruh terhadap motivasi kader dikarenakan adanya dukungan dari tenaga kesehatan setempat. Adanya hubungan interpersonal yang baik saling percaya, komunikasi, dan dialog interaktif antara kader dengan tenaga kesehatan setempat turut memotivasi kader dapat melaksanakan tugasnya secara optimal (20). Data menunjukkan kader di wilayah Puskesmas Gedangan memiliki motivasi yang lebih baik dibandingkan dengan kader wilayah Puskesmas Pagelaran dikarenakan dukungan tenaga kesehatan di wilayah Puskesmas Gedangan juga lebih baik dibandingkan wilayah Puskesmas Gedangan.

Pengetahuan kader di wilayah Puskesmas Pagelaran juga berhubungan signifikan terhadap kinerja kader, namun hal tersebut tidak berlaku di wilayah Puskesmas Gedangan. Hal ini dimungkinkan karena persentase kader yang berpendidikan SMP lebih banyak di wilayah Pagelaran dibandingkan dengan Gedangan. Teori menjelaskan bahwa tingkat pendidikan seseorang turut berpengaruh terhadap tingkat pengetahuannya dikarenakan dari jenjang pendidikan tersebut dapat membentuk pola nalar dan pikir seseorang (21). Meskipun demikian, pengaruh pendidikan terhadap kinerja kader tidak besar bila dibandingkan dengan peran motivasi terhadap kinerja kader. Tidak semua kader mendapatkan kesempatan yang sama untuk mendapatkan sharing ilmu ataupun memperbarui melalui penyegaran pengetahuan dari agenda pelatihan kader ataupun refreshing kader. Beberapa kader menuturkan bahwa agenda pelatihan kader cenderung didominasi dan diikuti oleh koordinator kader saja, begitupun dengan agenda refreshing kader tidak bisa dilakukan secara rutin dikarenakan terkendala biaya penyelenggaraan. Hal ini sejalan dengan hasil penelitian Sutiani yang menyebutkan bahwa pengetahuan belum cukup untuk merubah perilaku seseorang karena 
perubahan perilaku membutuhkan proses yang kompleks dan waktu yang panjang (22). Oleh sebab itu, diperlukan adanya upaya penambahan ketrampilan dan pengetahuan di luar jenjang pendidikan formal salah satunya melalui pelatihan kader secara merata untuk dapat meningkatkan kinerja kader (23) pada wilayah dengan stunting yang tinggi.

Temuan penelitian ini menunjukkan bahwa lama menjadi kader tidak mempunyai pengaruh langsung dan tidak langsung melalui pengetahuan dan motivasi terhadap

\section{DAFTAR PUSTAKA}

1. Kementerian Kesehatan Republik Indonesia. Kemenkes No. 1955/MENKES/SK/XII/2019 tentang Standar Antropometri Penilaian Status Gizi Anak. Jakarta: Direktorat Jenderal Bina Gizi dan Kesehatan Ibu Anak; 2011.

2. Tim Nasional Percepatan Penanggulangan Kemiskinan. 100 Kabupaten/Kota Prioritas untuk Intervensi Anak Kerdil (Stunting). Jakarta: Tim Nasional Percepatan Penanggulangan Kemiskinan; 2017.

3. Dinas Kesehatan Kabupaten Malang. Laporan Data Penilaiain Status Gizi Balita. 2016-2017. Malang: Dinas Kesehatan Kabupaten Malang; 2016.

4. Kementerian Desa, Pembangunan Daerah Tertinggal, dan Transmigrasi Republik Indonesia. Buku Saku Desa dalam Penanganan Stunting. Jakarta: Direktur Jendral Pembangunan dan Pemberdayaan Masyarakat Desa; 2017.

5. Yanti SV, Hasballah K, dan Mulyadi. Studi Komparatif Kinerja Kader Posyandu. Jurnal IImu Keperawatan. 2016; 4(2); 1-11.

6. Lukwan. Kontribusi Pengetahuan Kader terhadap Kinerja Kader Posyandu di Puskesmas Matandahi Konawe Utara. Jurnal Penelitian dan Pengembangan Pelayanan Kesehatan. 2018; 2(1); 17-22.

7. Fatmawati NL. Hubungan Motivasi Kader Dengan Pelaksanaan Peran Kader Posyandu di Kelurahan Sumbersari Kecamatan Sumbersari Kabupaten Jember. [Skripsi]. Universitas Jember, Jember. 2012.

8. Namazzi G, Okuga M, Tetui M, et al. Working with Community Health Worker to Improve Maternal and Newborn Health Outcomes: Implementation and Scale-Up Lessons from Eastern Uganda. Global Health Action. 2017; 10(4); 71-81.

9. Singh D, Negin J, Orach CG, and Cumming R. Supportive Supervision for Volunteers to Deliver Reproductive Health Education: A Cluster Randomized Trial. Reproductive Health. 2016; 13(1); 1-10.

10. Roberton $\mathrm{T}$, Applegate J, LeFevre $\mathrm{AE}$, et al. Initial Experiences and Innovations in Supervising Community Health Workers for Maternal, Newborn, and Child Health in Morogoro Region. Tanzania. Human Resource for Health. 2015; 13; 1-12.

11. Vareilles G, Pommier J, Marchal B, and Kane S. Understanding the Performance of Community Health Volunteers Involved in the Delivery of Health kinerja kader posyandu dalam program pencegahan stunting di wilayah Puskesmas Pagelaran dan Gedangan. Motivasi merupakan faktor dominan yang konsisten berpengaruh terhadap kinerja kader. Pada puskemas dengan angka stunting tertinggi, disamping motivasi, pengetahuan juga berpengaruh terhadap kinerja kader. Oleh karena itu upaya membangun motivasi menjadi strategi kunci dalam meningkatkan kinerja kader yang dapat diberikan dalam bentuk dukungan moril mulai dari lingkungan keluarga, masyarakat, dan tenaga kesehatan setempat.

Programmes in Underserved Areas: a Realist Synthesis. Implementation Science. 2017; 12(22); 112.

12. Mpembeni R, Bhatnagar A, LeFevre A, et al. Motivation and Satisfaction Among Community Health Workers in Morogoro Region, Tanzania: Nuanced Needs and Varied Ambitions. Human Resources for Health. 2015; 13; 1-10.

13. Akintola $\mathrm{O}$ and Chikoko G. Factors Influencing Motivation and Job Satisfaction among Supervisors of Community Health Workers in Marginalized Communities in South Africa. Human Resources for Health. 2016; 14(54); 1-15.

14. Tseng $\mathrm{Y}$, Griffiths $\mathrm{F}, \mathrm{Kadt}$ J, et al. Integrating Community Health Workers Into the Formal Health System to Improve Performance: A Qualitative Study on the Role of On-Site Supervision in the South African Programme. Health Services Research. 2019; 9(2); 1-11.

15. Greenspan JA, McMahon SA, Chebet JJ, Mpunga M, Urassa DP, and Winch PJ. Sources of Community Health Worker Motivation: A Qualitative Study in Morogoro Region, Tanzania. Human Resources for Health. 2013; 11; 1-12.

16. Kane $\mathrm{S}$, Kok $\mathrm{M}$, Ormel $\mathrm{H}$, et al. Limits and Opportunities to Community Health Worker Empowerement: A Multi-Country Comparative Study. Social Science and Medicine. 2016; 164; $27-$ 34.

17. Agustian AG. Revolusi Mental Berbasis ESQ: Kecerdasan Emosi dan Spiritual. Edisi Pertama. Jakarta: Indonesia Arga Tilanta; 2016.

18. Wijaya IMK, Murti B, dan Suriyasa P. Hubungan Pengetahuan, Slkap, dan Motivasi Kader Kesehatan Dengan Aktivitasnya dalam engendalian Kasus Tuberkulosis di Kabupaten Buleleng. Jurnal Magister Kedokteran Keluarga. 2013; 1(1); 38-48.

19. Susanto F, Claramita M, dan Handayani S. Peran Kader Posyandu dalam Pemberdayaan Masyarakat Bintan. Berita Kedokteran Masyarakat. 2017; 33(1); 13-18.

20. Kok MC, Kane SS, Tulloch O, et al. How Does Context Influence Performance of Community Health Workers in Low and Middle Income Countries? Evidence form the Literature. Health Research Policy and Systems. 2015; 13; 1-14.

21. Rosdiana Y. Widjajanto E, dan Kapti RE. Pengetahuan sebagai Faktor Dominan Efikasi Diri Kader dalam Melakukan Deteksi Dini Gangguan Jiwa. Jurnal 
Kedokteran Brawijaya. 2018; 30(2); 138-141.

22. Sutiani R, Lubis Z, dan Siagian A. Gambaran Pengetahuan dan Ketrampilan Kader dalam Pemantauan Pertumbuhan Bayi dan Balita di Wilayah Kerja Puskesmas Desa Lalang Tahun 2014. Jurnal Gizi Kesehatan Reproduksi dan Epidemiologi.
$2014 ; 1(3) ; 1-8$.

23. Muzakkir M, Faktor-faktor yang berhubungan Dengan Kinerja Kader Posyandu di Wilayah Kerja UPTD Puskesmas Kaledupa Kabupaten Wakatobi Propinsi Sulawesi Tenggara. Jurnal IImiah Kesehatan Diagnosis. 2013; 2(2); 136-142. 